\title{
The Good, the Bad and the Unthinkable of Learner Autonomy in $\mathrm{EFL}^{1}$
}

\section{(Lo bueno, lo malo y lo impensable de la autonomía en el aprendizaje de ILE)}

Henry Sevilla Morales ${ }^{2}$

Universidad Nacional, Costa Rica

\begin{abstract}
This study assesses the relation between self-evaluation and the development of learner autonomy (LA) in English as a foreign language (EFL). Using action-research, the investigation included 22 first-year students taking an oral communication and listening comprehension course in English at the Universidad Nacional, Costa Rica. Data collection instruments included weekly plan sheets, student diaries, and student portfolios and were subject to several validity measures. Broadly, findings suggest a connection between self-evaluation and the promotion of LA in EFL in four areas: time management, self-awareness and goal-setting, sense of achievement, and skills integration.
\end{abstract}

1 Recibido: 22 de julio de 2019; aceptado: 23 de octubre de 2019. Acknowledgements: This paper presents preliminary findings from the research project "La autoevaluación como estrategia didáctica para potenciar la autonomía en el aprendizaje de inglés como lengua extranjera" (código SIA 0393-16), financed by the Universidad Nacional (UNA). I wish to thank the authorities of the Escuela de Literatura y Ciencias del Lenguaje (2016-2021) for their continuous support and helpful academic guidance. I also want to thank Lelia Villalobos Rodríguez, Sherry Gapper Morrow, Sonia Rodríguez Salazar, and posthumously, Allan Pineda Rodríguez, for their insights for the initial proposal of this project. My final word of gratitude goes to Geovanni Corrales Ramírez, my 2018 student assistant, for his invaluable contribution and unmatched enthusiasm throughout the data collection and coding process.

2 Escuela de Literatura y Ciencias del Lenguaje. Correo electrónico: henry.sevilla.morales@una.ac.cr

LETRAS 67 (2020), ISSN 1409-424X; EISSN 2215-4094

Doi: http://dx.doi.org/10.15359/rl.1-67.6

www.revistas.una.ac.cr/index.php/letras 


\section{Resumen}

Se analiza la relación entre la autoevaluación del estudiante y el desarrollo de la autonomía en el aprendizaje del Inglés como Lengua Extranjera (ILE). Mediante la investigación-acción, el estudio incluyó veintidós estudiantes de primer ingreso de un curso de comunicación oral y comprensión auditiva de la Universidad Nacional, Costa Rica. Los datos fueron recabados mediante planes semanales, diarios del estudiante y portafolios del estudiante y sometidos a validación metodológica. Se concluye que hay una conexión entre la autoevaluación y el desarrollo de autonomía en el aprendizaje de ILE en cuatro áreas: manejo del tiempo, autoconsciencia, sentido de logro e integración de destrezas.

Keywords: English as a foreign language, action research, learning strategies

Palabras clave: inglés como lengua extranjera, investigación-acción, estrategias de aprendizaje

\section{Introduction}

Although postulating the origin of learner autonomy (LA) in education is by far an ambitious undertaking, authors such as Pichugova, Stepura and Pravosudov trace it back to Henri Holec's 1981 publication of the book Autonomy and Foreign Language Learning. Back then, Holec conceived autonomous learning as being able to "take responsibility for [the] learning process in terms of determining the objectives, choosing the content material to study, selecting the strategies and methods of study, [and] monitoring and evaluating their learning." "The inception of the construct hence parallels the paradigm shifts experienced in language instruction the 1980s, supported by ideas of learner-centeredness enforced by renowned authors such as David Nunan. ${ }^{4}$ Today, the literature uses related concepts to refer to

3 Inna L. Pichugova, Svetlana N. Stepura and Matvey M. Pravosudov, "Issues of Promoting Learner Autonomy in EFL Context," SHS Web of Conferences 28 (2016): 1-4 (1). DOI: 10.1051/ shsconf/20162801081.

4 Nilcan Bozkurt and Fadime Yalcin Arslan, "Learner Autonomy in Language Learning: Syrian Refugee EFL Learners' Perceptions and Readiness," Multidisciplinary Journal of Educational Research 8, 2 (2018): 115-145 (117). DOI: 10.17583/ remie.2018.3028. 
the subject, "with nuances based on versions of it such as [...] learner independence, self-direction, awareness, andragogy, autonomous learning, and independent learning," ${ }^{5}$ as well as self-education, ${ }^{6}$ selfregulated learning, ${ }^{7}$ and many others. While theoretical discussions around LA in language instruction have been around for a good while now, ${ }^{8} \mathrm{empirical}$ studies on this subject remain rather scarce in comparison to those reported in areas such as methodology and assessment.

In Costa Rica, efforts to tackle this issue have been recorded more systematically in the past six years by Barrantes and Olivares, Zamora and Chaves, López, and Sevilla and Gamboa, ${ }^{9}$ but these account for only isolated initiatives with little or no financial support from universities. At the core of this issue is that fact that most of these investigations have been sporadic and fragmentary, making it difficult to track down the long-term evolution of the populations studied in terms of LA development. ${ }^{10}$ To help bridge this gap, the current paper discusses preliminary findings from a two-year research project which assesses the incidence of self-evaluation as a strategy to promote LA across three English as a Foreign Language (EFL) programs in the School of Literature and Language Sciences (Escuela de Literatura y

5 Pichugova, Stepura and Pravosudov, 1.

6 Rimma Sagitova, "Students' Self-Education: Learning to Learn Across the Lifespan," Procedia Social and Behavioral Sciences 152 (2014): 272-277. DOI: 10.1016/j.sbspro.2014.09.194.

7 Daniel C. Moos and Alyssa Ringdal, "Self-Regulated Learning in the Classroom: A Literature Review on the Teacher's Role," Educational Research International, (2012): 1-15. DOI: $10.1155 / 2012 / 423284$.

8 Pichugova, Stepura and Pravosudov, 1.

9 Lena Barrantes and Cinthya Olivares, "A Closer Look into Learner Autonomy in the EFL Classroom," Revista de Lenguas Modernas 19 (2013): 325-343; Eduardo Zamora and Olga Chaves, "Plans of Improvement: A Resource to Enhance Performance and Autonomy in EFL Courses," Revista de Lenguas Modernas 18 (2013): 285-298; Patricia López, "Empowerment Pedagogy: Personal Improvement Goal in Higher Education," II Congreso Internacional en Linguística Aplicada (CONLA-UNA): Pérez Zeledón: Universidad Nacional, 28-30 Oct. (2015): 244-254; Henry Sevilla and Roy Gamboa, "Student Self-Evaluation and Autonomy Development in EFL Learning," Revista de Lenguas Modernas 25 (2016): 199-222.

10 Ian Tudor has described this kind of long-term autonomy as the political dimension of autonomy. See: Ian Tudor, The Dynamics of the Language Classroom (Cambridge: Cambridge University Press, 2001) 119. 
Ciencias del Lenguaje, ELCL) and it is framed within the principles of action research.

The study was arranged into four action-research cycles: (1) identification of educational needs, (2) action-plan design, (3) systematic observation of the action plan, and (4) rigorous reflection on the results. Informants comprised 22 first-year students enrolled in an oral communication class in a bachelor's program in English during the first semester of 2018. Data were collected from several instruments such as weekly plan sheets, student diaries, and student portfolios, and they were validated through various procedures including triangulation, prolonged engagement in the field, respondent validation, and instrument pilot-testing. Raw data were later coded to devise categories of analysis following Freeman's (1998) stages for data analysis and interpretation.

By and large, findings suggest a link between self-evaluation and the promotion of LA in four core areas: time management, self-awareness and goal-setting, sense of achievement, and skills integration. Nevertheless, the study reports downsides such as evidence of academic frustration, and the added downside that it was not possible to determine the extent to which the positive outcomes will translate neatly into LA in the long run. Preliminarily, the study supports the claim that these types of initiatives require extensive support from institutional authorities and joint efforts between stakeholders, curriculum developers, and instructors to make LA a priority in EFL. These apparently unthinkable actions are, however, what this paper advocates in the conclusion. The investigation makes several noteworthy contributions for theory and practice: (1) It expands the body of empirical literature on the topic; (2) it sheds light on the benefits and the challenges of running similar projects in EFL programs; and (3) it proposes methods that can be reconstructed in teaching and research practice. 


\section{Theoretical Background}

To situate the paper theoretically, this section touches upon three subtopics: the status quo of LA, empowerment pedagogy and complexity theory, and self-evaluation as a strategy to promote LA in EFL.

\section{The Status Quo of Learner Autonomy: Needs and Current Developments}

In the new geopolitical order, learner autonomy boasts a pivotal role as a roadmap to learning skills beyond the classroom boundaries. To achieve this, the conditions must be provided to develop not only the technical knowledge to perform specific tasks, but also critical thinking and otherhigher order abilities through self-reflection and self-regulation. According to Cabrera, this can only be accomplished when independent, self-directed learning has taken place. Learner autonomy, according to the author, means that the students "understand the demands of the learning tasks, and set a series of competences, skills, and habits towards a specific learning goal [...]" (author's translation). ${ }^{11}$

In language instruction, LA becomes an even more vital element since learners are expected to develop high degrees of proficiency which demand large amounts of out-of-class work, not to mention the fact that they must to stay up-to-date with a changing society that requires shaping and reshaping procedural knowledge. Monereo and Pozo agree with this when they reflect on the short-term expiry of knowledge:

[...] otro de los rasgos que definen el conocimiento en esta sociedad, $[\ldots]$ es la aceleración en el ritmo de producción y, por tanto, su creciente caducidad. Aunque sin duda hay saberes más imperecederos que otros, la celeridad en la producción del conocimiento, y la instantaneidad en su distribución, añaden nuevas incertidumbres sobre la relevancia de los saberes que se transmiten a

11 Isaac Cabrera, "Autonomía en el aprendizaje: Direcciones para el desarrollo en la formación profesional," Actualidades Investigativas en Educación 9, 2 (2009): 1-22 (11-12). 
los alumnos. Aun cuando se tenga la certeza de que hoy son saberes necesarios, en muchos casos no es posible tener casi ninguna certeza de que van a ser igualmente necesarios o relevantes dentro de diez o incluso cinco años. ${ }^{12}$

From this quotation, it follows that students must be prepared perhaps not only to learn, but also to "re-learn and unlearn" on a constant basis, as Cabrera has argued. ${ }^{13}$ This is perhaps truer in the context of EFL, where learners typically receive less linguistic exposure and therefore get fewer communication opportunities than they would in, say, an ESL scenario. In light of this need, Gamboa ${ }^{14}$ and Cabrera ${ }^{15}$ argue that teaching strategies provide a starting point to attain life-long learning, but more importantly to face the numerous challenges of our evolving societies. ${ }^{16}$

Investigating LA, however, is not without limitations. One of them is the construct's "vast and developing" nature, which makes unifying an operational definition for it difficult; ${ }^{17}$ another-and perhaps the greatest of all - is the impossibility to study LA beyond the classroom setting, especially in the long run. According to Tudor (2001), autonomy outside the classroom has been circumscribed within the "political dimension," 18 and it is a most-pursued skill since it transforms individuals from mere learners into actual language users. The problem is that systematic inquiry of this kind of autonomy requires longitudinal studies, a substantial amount of research resources, and high degrees of motivation on the part of researchers. This may help

12 Carles Monereo and Juan Ignacio Pozo, "La cultura educativa en la universidad: nuevos retos para profesores y alumnos," en La Universidad ante la nueva cultura educativa: enseñar y aprender para la autonomía (Madrid: Síntesis, 2003) 3.

13 Cabrera, 2.

14 Roy Gamboa, "La autoevaluación del estudiante para potenciar la autonomía en el aprendizaje," Curso: Didáctica Universitaria para Profesores, Universidad de Costa Rica (2013) [unpublished manuscript].

15 Cabrera, 9.

16 We will return to teaching strategies in the sub-section "Self-Evaluation: A Vehicle to Learner Autonomy."

17 See Sevilla and Gamboa (2016) 204.

18 Tudor, 118-119. 
explain why most autonomy studies in Costa Rica are cross-sectional and focus on small samples and populations, ${ }^{19}$ and why in other countries, even when larger samples have been used, investigations do not seem to deal with the long-term study of LA. ${ }^{20}$

\section{Empowerment Pedagogy and Complexity Theory Today}

Empowerment pedagogy (EP) developed from the postulates of Paulo Freire's critical pedagogy theory. ${ }^{21}$ According to López, Freire (1970) challenged the long-held paradigms of banking education where knowledge was passively "transferred" from teacher to learner and advocated for a type of learning that fostered "criticism, students' commitment to their learning process, a sense of belonging and identity, the creation of knowledge through dialogue, and the development of learning autonomy." ${ }^{22} \mathrm{EP}$ also implies acknowledging that, to a large extent, "students are part of an oppressing process where educational aspects, including content and evaluation, are imposed upon them[...]" Empowering learners, López claims, "promotes students' growth, autonomy, criticism, confidence, and self-reliance." ${ }^{23}$ In the view of Torres, EP must inevitably involve democratic, participatory instruction, where the student is at the center of the learning process and becomes an empowered agent of change; his power must be recognized as a transformative element for society at large. That implies that an educational system should center on critical reflection on the institution, the teachers, and the students' performance in search for individual and collective decision-making. ${ }^{24}$ Discussing the place for

19 See: Barrantes and Olivares; Zamora and Chaves; Gamboa; López; and Gamboa and Sevilla.

20 See Craig Gamble, Jonathan Aliponga, Michael Wilkins, Yasuko Koshiyama, Keiko Yoshida and Shirley Ando, "Examining Learner Autonomy Dimensions: Students' Perceptions of their Responsibility and Ability," JALT Conference Proceedings (2012): 263; and Bozkurt and Arslan, 121.

21 López, 244-246.

22 Qtd. in López, 245.

23 López, 251.

24 Analí Torres, "La educación para el empoderamiento y sus desafíos," Sapients. Revista Universitaria de Investigación 10, 1 (2009): 89-108 (92-93). 
EP in childhood education, Loizou and Charalambous have highlighted the following:

[...] an empowerment framework encompasses participation actions that assume children actively participate in their world," and that "true participation is accompanied by providing space for children to share their voice, treating them as social partners who participate in the development of their lives and the world..$^{25}$

Based on the above, in the current research EP is conceived as a condition involving not only the students, but also teachers as mediators between policy-makers, the curriculum, and the learners. In the words of Levitt, aiming for teacher empowerment plays a key role in enforcing a liberating education since instructors may help "disturb the balance of the system and bring needed educational reforms to schools." ${ }^{26}$ Within this context, far from over-empowering students towards uncritical control of their own learning, this study advocates a negotiated learning experience, where the presence of power, in its most positive sense, opens spaces for autonomous learning for the collective growth of society. ${ }^{27}$

With that said, let us now turn to complexity theory (CT). Originating in Chaos Theory, CT holds that reality is complex and therefore impossible to understand via the mechanisms of the natural sciences where reality is understood as a continuum of causes and effects. ${ }^{28}$ In the classroom contexts, learning is conceived as dynamic, changing and elusive, thus making it not only difficult but also risky to formulate causes and effects between the current project and the

25 Eleni Loizou and Nasia Charalambous, "Empowerment Pedagogy," Journal of Research in Childhood Education 31, 3 (2017): 440-452 (441).

26 Roberta Levitt, "Freedom and Empowerment: A Transformative Pedagogy of Educational Reform," Educational Studies, 44 (2008): 47-61 (57). DOI: 10.1080/00131940802225085.

27 See Bill Johnston, "Putting Critical Pedagogy in its Place: A Personal Account," TESOL Quarterly 33, 3 (1999): 560.

28 Louis Cohen, Lawrence Manion and Keith Morrison, Research Methods in Education, $7^{\text {th }}$ ed. (New York: Routledge, 2011), 7-9. 
students' reported behaviors. ${ }^{29}$ In agreement with this, Tamjid asserts that language learning does not escape this condition given that languages are the epitomes of evolution and change. ${ }^{30}$ This partly explains why, for example, a student may get to master a complex structure but fail to internalize one with a similar degree of complexity. ${ }^{31}$ In like manner, CT helps understand why a given strategy or methodology yielded different results in two or more populations with similar characteristics. The reason for this, Soleimani argues, is that the language classroom is such a complex space that its dynamics are shaped by a myriad of factors, making it virtually impossible to predict unequivocal learning outcomes. Thus, CT is much more useful to explain teaching precepts than prescribe them. ${ }^{32}$ Broadly, Larsen-Freeman (1997) and Van Lier (2004) have explained that CT, among other characteristics:

1. Warns against settling for simple solutions prematurely, as well as against rejecting contrasting viewpoints.

2. Provides some fresh light on SLA phenomenon. [sic]

3. Discourages cause/effect-based theories.

4. Underscores the importance of details

5. Reminds us to hold the whole and to find a unit of analysis that allows this. ${ }^{33}$

For Freeman (1997), languages go through periods of chaos and order, and their uppermost creative development occurs at the border between them a state Waldrop (1992) called the edge of chaos. ${ }^{34}$ According to Finch (2001), "the concept of the classroom "on the edge

29 See Cohen, Manion and Morrison, 7.

30 Nasrin Hadidi Tamjid, "Chaos / Complexity Theory in Second Language Acquisition," NovitasROYAL 1, 1 (2007): 12.

31 Tahjid, 15.

32 Hassan Soleimani, "Complexity Theory and CALL Curriculum in Foreign Language Learning," International Journal of Applied Linguistics \& English Literature 3, 3 (2014): 19-25 (19). DOI: 10.7575/aiac.ijalel.v.3n.3p.19.

33 Qtd. in Tamjid, 15-16.

34 Qtd. in Tamjid, 16. 
of chaos,' that is, in a maximum state of learning, implies sensitivity to every variation of input $[\ldots]$, being 'adaptive' to changing needs and preferences, and 'emerging' of new learning structures." ${ }^{35}$ This chaotic nature of the environment, as Tudor anticipated at the birth of the $21^{\text {st }}$ century, proposes that embracing chaos makes education not only a realistic endeavor, but also a more honest one. ${ }^{36}$ Tudor insists that the success of education does not lie in the idyllic order which we have fabricated in the minds of teachers, but in our capacity to respond to the complexities of the language classroom within the specificities of each context. This indicates that we must accept language education for what it is rather than for what we would like it to be, thus suggesting a change in the way we understand and conduct research - a change from positivistic to naturalistic (emic) studies. ${ }^{37}$

\section{Self-Evaluation: A Vehicle for Learner Autonomy}

Before discussing the link between self-evaluation as a learning strategy and learner LA development, let us briefly look into the principles of on-going assessment, which have been used in this study as a theoretical platform to run the action research (see methodology section). Among other principles, Andrade and Cizek explain that ongoing assessment requires that: (1) students take charge of their own responsibilities, (2) objectives be clear and specific, (3) action plans be designed to meet the desired goals, and (4) students evaluate their own learning outcomes through formative feedback, self and peer assessment, and reflection. ${ }^{38} \mathrm{Also}$ referred to as sustainable assessment, on-going assessment advocates meaningful learning practices as a way to cultivate "co-operative interdependence, relatedness (or

35 Qtd. in Tamjid, 16.

36 Tudor, 42.

37 Tudor, 40-41.

38 Heidi Andrade and Gregory Cizek, Handbook of Formative Assessment (New York: Routledge, 2010) 8 . 
affiliation), autonomy and, consequently, enduring and sustainable lifelong learning skills." ${ }^{39}$

In the present study, on-going assessment is combined with self-evaluation as a learning strategy to develop LA in EFL learning. Self-evaluation is in turn coupled with teaching techniques such as student diaries, weekly plan sheets, portfolios, and strategy-assessment checklists, all of which according to recent research help foster LA. The initiative also arises from findings reported by related research in Costa Rica (e.g., Barrantes and Olivaress; Zamora and Chaves; Gamboa; López; and Gamboa and Sevilla, 2016), where positive LA results are found when using systematic learning strategies across varied higher education settings.

According to Monereo and Pozo, a learning strategy is a series of guided actions devised to help students to deal with the complexities of life, and it is broader than a learning plan and transcends classroom limits. ${ }^{40}$ Within the spectrum of learning strategies, self-evaluation has been vindicated as one of the best ways to foster LA. In the view of Calatayud, self-evaluation is by far the best learning strategy to teach learners to critique and reflect upon their learning process, ${ }^{41}$ with direct benefits such as developing self-awareness, fostering responsibility, and having opportunities for self-motivation; teachers, for their part, can use this strategy to assess their students' progress and propose pedagogical changes in situ. Along the same lines, Bolancé, Cuadrado, Ruiz, and Sánchez stress that self-evaluation must be conceived as always allowing room for improvement. The authors seem to agree with Calatayud's view on LA when they issue the following claim: "la autoevaluación se convierte en un elemento

39 Cohonen (2012), Qtd. in Carol J. Everhard and Linda Murphy, Assessment and Autonomy in Language Learning (Houndmills, Basingstoke, Hampshire: Palgrave MacMillan, 2015) 17.

40 Monereo and Pozo, 9.

41 Qtd. in Gamboa, 3. 
clave de cambio y transformación para la mejora de la educación, como parte imprescindible del uso 'real' de la autonomía." ${ }^{22}$

For the actual implementation of self-evaluation, Gamboa endorses several techniques, such as the self-evaluation block, the weekly plan of improvement, teacher-created self-reflection instruments, the student diary, and the portfolio. ${ }^{43}$ Classroom diaries are also a good idea, as long as they are read by the professor on a regular basis for the students to receive feedback on the learning process and make changes thereupon.

\section{Methodology}

\section{Research Type}

Given its nature and purpose, the present study used an actionresearch approach. This type of research seeks to solve an existing educational need by conducting a four-stage investigation cycle: planning, conducting, observing, and evaluating an action plan to solve the teaching problem. According to Latorre, action research aims to:

1. improve teaching and social practices while trying to better understand such practices

2. permanently articulate research, action, and preparation.

3. take a close look at reality by linking knowledge and change; [and]

4. give teachers an active role in research [author's own translation]. ${ }^{44}$

The study is further classified as practical action research, described by Gay, Mills, and Airasian as a type of inquiry where

42 Juana Bolancé, Francisco Cuadrado, José Ramón Ruiz and Fernando Sánchez, "La autoevaluación de la práctica docente como herramienta para la mejora del proceso de enseñanza y aprendizaje del alumnado," Avances en Supervisión Educativa, 18 (2013) 15.

43 Gamboa, 4.

44 Antonio Latorre, La investigación-acción: Conocer y cambiar la práctica educativa (Barcelona: Graó, 2014) 27. 
"teacher researchers will choose their own areas of focus, determine their data collection techniques, analyze and interpret the data, and develop action plans based on the findings. " ${ }^{45}$ In terms of the measures used, the study is qualitative since the data were collected from a natural environment, it was not based on statistical analysis, and it considered subjective, co-constructed realities that emerged from the data. ${ }^{46}$ The investigation is exploratory because the phenomenon has not been deeply studied in Costa Rica. Hernández et al. highlight that this type of exploration helps us become familiar with recently unexamined phenomena, investigate new issues, and set future research agendas. ${ }^{47}$

\section{Participants and Setting}

Participants included 22 students ( 17 females and 5 males, ages 17 to 27) in an EFL program belonging to the ELCL-UNA English Department. They were enrolled in their first oral communication and listening comprehension course in the Bachelor's in English, in their first semester of their freshman year. They also came from different socio-economic backgrounds and geographical locations of Costa Rica, including the Central Valley, Guanacaste, and Limón. The researcher used convenience sampling, a type of nonrandom sampling strategy that allowed the use of an intact class as informants for the study, especially because the goal was not to generalize results to larger populations, but to "describe a particular context in depth." 48 Roughly, the classroom dynamics followed a constructivist-humanist philosophy, where students were empowered to negotiate their learning with the professor-researcher. This implied conforming to course objectives and topics while at the same time letting students decide on the educational needs (goals, topics, and strategies) that

45 Larry R. Gay, Geoffrey E. Mills and Peter Airasian, Educational Research: Competencies for Analysis and Applications, $9^{\text {th }}$ ed. (Upper Saddle River, New Jersey: Pearson, 2009) 489.

46 Roberto Hernández, Carlos Fernández and María del Pilar Baptista, Metodología de la investigación, $5^{\text {th }}$ ed. (Mexico D.F.: McGraw-Hill) 3.

47 Hernández, Fernández and Baptista, 79.

48 Gay, Mills and Airasian, 135-136. 
they considered most relevant; opening spaces for self-reflection in and out of the classroom; and giving and receiving feedback on performance, goals and skills, and areas where progress was actually being made. The action plan thus reshaped classroom dynamics insofar as it fostered a culture of continuous improvement and reflection on the one hand, and of interactive, constructive, and flexible learning strategies on the other.

\section{Researcher Positionality}

Consistent with the underpinnings of $\mathrm{CT}$, the researcher (i.e., Sevilla) would like to disclose his positionality within the educational research setting. Ontologically, he envisions social reality as fragmented, unpredictable, and context-bound; to him, that reality (of which language learning is but a minute example) is co-constructed by the interaction of a plethora of factors which converge in time and space over a given issue, and it is shaped by the worldviews and experiences of both the researcher and the participants involved. As a result of this ontological view, epistemologically, he adheres to an emic perspective, where the researcher must come into contact with the informants, and therefore affect both data analysis and interpretation of results. He is aware of his role as an insider (a group member), which helps him approach the inquiry with a high degree of honesty and reflexivity, ${ }^{49}$ and in turn, take the necessary precautions to counterbalance potential threats to validity and dependability, as discussed below.

\section{Procedures}

On the second day of class (Feb. 16, 2018), the investigator explained the research goal, data collection procedures, and participants' role if they accepted to participate in the study. Upon accepting, they read and signed a letter of consent where they guaranteed full access to

49 For a full discussion on reflexivity, see: Marilyn Lichtman, Qualitative Research in Education: A User's Guide, $3^{\text {rd }}$ ed. (Thousand Oaks, California: SAGE Publications, 2013) 164-165. 
the data they provided throughout the semester. The stages comprising the present study are described in this section.

\section{Stage 1}

The first stage consisted of pinpointing educational needs, for which an autonomy assessment instrument was developed for the students to fill out. The instrument sought to collect qualitative and quantitative data on the learners' autonomy-related habits, as identified previously by Sevilla and Gamboa..$^{50}$ In short, participants rated their level of agreement with ten statements through a six-point bipolar scale which included statements such as "In my English experience so far, I...: 1. am able to effectively organize my time; 2 . am able to set learning goals; 3 . devote a consistent number of weekly hours to reinforce my learning;" etc. In addition to that, they were asked to elaborate on their level of learning autonomy before the action plan took place (see appendix 1).

\section{Stage 2}

The second stage comprised the design of an action plan, as follows: The researcher first selected a set of instruments to solve the needs identified: (i) a weekly plan of improvement (POI; see appendix 2), (ii) a student diary (see appendix 3), and (iii) a final portfolio. In the POI, the participants: (a) chose the content they wanted to reinforce, (b) designed an activity to process such content, (c) set a schedule to do the activity, (d) assessed the effectiveness of the activity, and (e) reflected on courses of action to adopt on the following week. In the student diary, they assessed their overall feelings, participation, and perceived progress during the week; and they shared these with the professor for formative feedback and possible methodological changes. In the final portfolio, informants included fifteen POIs with the corresponding corrections provided during the semester and an

50 Sevilla and Gamboa (2016), 210-215. 
introduction and a conclusion reflecting upon the challenges and accomplishments of the project.

\section{Stage 3}

The third stage (systematic observation) was concurrent with stage two (action plan design); that is, as the plan was running, the researcher took note of the students' progress, needs, and wants, and made the necessary changes in the classroom.

\section{Stage 4}

The fourth and last stage (systematic reflection on the results) was carried out during and after the project's completion. During the project, students would share their POIs and student diaries with the professor-researcher for feedback on a weekly basis. This allowed both researcher and informants to engage in reflective dialogue about progress, must-improve areas, and other relevant aspects of the project. It also allowed for adjustments in the current class and suggestions for further implementation in other settings, in accordance to the cyclical nature of action research. After the semester was over, reflection continued in the form of systematic analysis of raw data to devise codes and then categories of analysis (see Data Analysis section for details).

\section{Validity and Dependability Measures}

To counterbalance threats to validity, the researcher used a series of measures, such as descriptive validity ("factual accuracy of the account"), interpretive validity (notion of fidelity), theoretical validity (theory used as explanation for the results; see discussion section), and a number of dependability steps including prolonged engagement in the field, persistent observation, instrument triangulation, leaving audit trails, and avoiding causality where only correlation existed. ${ }^{51}$ While qualitative research is prone to (and often celebrates) subjectivity, these

51 Cohen, Manion and Morrison, 181-202. 
measures helped achieve a fair degree of accuracy and trustworthiness in the collection and interpretation of the data.

\section{Data Analysis}

This section presents the results gathered via the three instruments described above. To arrive at the results, the author followed Lichtman's steps for inductive analysis of data:

1. Initial coding. Going from responses to summary ideas of the responses

2. Revisiting initial coding

3. Developing an initial list of categories

4. Modifying that list based on additional rereading [and]

5. Revisiting your categories $[\ldots] .^{52}$

For the purpose of organization, data will be depicted according to the five categories of analysis which emerged during the data collection and interpretation process: (1) time management, (2) self-awareness and goal-setting, (3) sense of achievement, (4) skills integration, and (5) academic frustration. ${ }^{53}$ Each category will include the main benefits and issues faced by the informants. To account for confidentiality, the citation codes will be used to report on the data are provided in table 1.

Table 1. Citation Codes for Data Analysis

\begin{tabular}{|l|l|l|}
\hline \multicolumn{1}{|c|}{ Instrument Type } & \multicolumn{1}{c|}{ Data Source } & \multicolumn{1}{c|}{ Citation Code } \\
\hline Weekly Plan & Oral Class Students & WP-001-022 \\
\hline Student Diary & Oral Class Students & SD-001-022 \\
\hline Final Portfolio & Oral Class Students & FP-001-022 \\
\hline
\end{tabular}

52 Lichtman, 251-255.

53 For further information on this type of data collection process: Henry Sevilla and Roy Gamboa, "Critical Incidents, Reflective Writing, and Future Teachers' Professional Identities," Revista de Lenguas Modernas 26 (2017): 233-255. 


\section{Time Management}

Data concerning this category shows a combination of positive and negative results, but evidence suggests improvements as the students gained experience in the project. For instance, on week 1 participant 16 states: "This was the first week and I have to admit that the most difficult thing for me was meet the schedule, I get easily distracted and it took me two days to finish this work" (WP-016, sic). On week 2, participant 2 reports: "In the first week I was confused, because I din't know when to start the homework or POI" (SD-002, sic). On week 7 , after having struggled with the schedule in previous weeks, informant 14 indicates: "the schedule this was not difficult to accomplish because this week I am not under stress, I feel relax because I have the time to work on the skills I need to improve, with patience" (WP, 014, sic). Similarly, on week 13 participant 16 claims to have been able to "stick to the schedule [because] the topic was interesting" (WP-016, week 13).

On the negative side, some learners who had apparently managed to organize their time well towards the middle of the semester reported difficulties resulting from excess of homework "and things." In participant 14's words:

This time the schedule was not as easy to meet like last week I feel tired and have many other homeworks and things I have study but also with all the motivation to keep up with univesity responsabilities, this activies always helped me to review all the topics seen in class (WP-014, week 9, sic).

Subject 7 admits difficulty meeting his own schedules because he is not used to doing so on a regular basis (WP-008, week 7), a statement supported by informant 5 in his final portfolio: "One thing that was [...] difficult for me was to follow the schedule, sometimes I wrote that I will start at 6:00, for example, and I started at 7:00 
because I get distracted" (FP-005, sic). Perhaps the best summary for this category comes from P-21, who states:

[...] it was difficult to manage the time and at first my thought was: why do we have to do this every week? It is a waste of time because it is not going to be useful at all, but I was wrong, I mean, it was not easy but was interesting and challenging and thanks to this project I have learned many things." (FP-021, sic)

\section{Self-Awareness and Goal-Setting}

Here, similar to the time management category, results showed a combination of positive results and issues faced. In the final portfolio, P-019 highlights the personal and intellectual growth derived from the project: "I recognize that my English bases are not good but with the development of work as the POI is extremely useful [...] This work involves my intellectual and personal growth [...]" (FP-019, sic). In the student diary, P-004 issues a similarly positive comment when she reports: "I've tried to make sure I'm pronouncing things correctly and I also enjoy reading the articles, surprisingly" (SD-004, sic). This student's use of the word "surprisingly" suggests that reading news articles was perhaps not her favorite learning technique before this project, of which she is fully aware and emphasizes by using a tag comma at the end of her comment. Other participants show awareness of their learning process in comments such as the following: "Although I'm not that participative, I feel like I really participated this week and that's great to learn more and more" (SD-016, sic); "In listening skills this lessons is very very improvement to me but in speaking I have very difficult" (SD-013, sic); and "as future translator, I think that is very important to learn new words every day in order to improve" (FP-007, sic).

With regard to goal-setting, a good piece of evidence comes from the student diary of P-002, who questions the usefulness of a learning technique and immediately thinks about a goal to improve 
the quality of his learning: "Honestly, I don't know if it's a good idea to watch videos with subtitles. I'm thinking to stop doing that for the next week to see how it goes" (SD-002, sic). Similarly, P-014 admits that on week 3 her performance was really low, but she instantly sets an improvement goal for the following week: "I wanted to participate many times, but there's something inside me pushing me back, this week for me was a 0 , I promised I am going to participate next week" (SD-014, sic).

The following two comments from the final portfolio capture the essence of the results for this category.

For me the POI is a tool for the student because you learn by yourself and that is one of the things that I enjoyed. I was discovering new things by myself and that helps me lot to improve my English. Because in week one I did not imagine me saying expressions like "hey you are barking up the wrong three" or "I see eye to eye with my brother." (FP-012, sic)

There is no other way to improve my English just practicing and doing this project helped me improve a lot. I would like to keep improving my English and reading articles and watching videos every week is a good idea. After this course, I hope to continue watching videos and reading articles every week as if I was still in the course. (FP-018, sic)

For both categories analyzed so far, the evidence suggests that the course tasks fostered the conditions for the emergence of some LA and the empowerment necessary to improve time management and set future learning goals.

\section{Sense of Achievement}

This category sought to inquire on students' perceptions of their own academic accomplishments. It differs from self-awareness and goal-setting in that it focuses explicitly on the students' perceived 
academic accomplishments, excluding the problems faced. Evidence from three data collection instruments shows positive outcomes at various levels. The first is in terms of pronunciation: "I learned about ways of pronunciation I didn't have idea of, just like foreign or other vs. otter"'(SD-016, sic). The second touches upon the psycho-emotional side of learning, with reports of improvement in overcoming stage fright during in-class activities: "The activities that we do in class help us to lose the fear of talking in public and also with the POI's [...]" (SD-016, sic). Likewise, in the third benefits were reported for managing to connect the project with summative assessments: "It [the weekly plan] was very effective; it also helped me to study for the oral test" (WP-005).

Similar to what participant 4 reported in self-awareness and goal-setting above, P-007 confesses that, after the project, he has developed an early taste for reading news articles in English, which he thinks will help him achieve future goals: "As incredible as this might sound, sometimes I found myself reading the news in English! For me this is something really good, because as I said, I want to live in England, and this will help me a lot" (FP-007). Participant 8 admits that he achieved more than he expected in terms of grammar and pronunciation, a point worth noting since we are dealing with a feeling of success in terms of skills integration (see next category). As the student puts it:

I could learn more that I could think, I am able to recognize part of the speech I mean if a word works as an adjective, noun, verb; moreover, I could link my pronunciation course with my oral course because I did many transcription in this portfolio." (FP-008, sic)

Further evidence on this category comes from the student diary, with the inclusion of comments such as these: "I really like the lessons, everytime I fell that I learn something new and that I can use it in a conversation or what I have to keep in mind [...]" (SD-014, sic); "I felt really comfortable talking with my classmates and professor because 
even if I don't know how to say something everyone is willing to help me" (SD-001); "I have 3 weeks here at the University and everyday learn new vocabulary. Also listen and accept the corrections of my professors and practice them" (SD-012, sic); "[...] first I felt a little scared because I don't speak English and it's hard for me, but now I feel more relax because I know the class and it's good" (SD-018, sic); and "my listening skills improve more than speaking skills, but both skills do it. I'm sure that each week I improve more and more" (SD-010, sic).

\section{Skills Integration}

Besides the gains reported above, the data indicate that the project also helped the students work on several skills and sub-skills. For example, P-014 claims to have integrated listening and vocabulary as she worked on the plans of improvement: "I feel even more prepared for the topics we are going to see in class, and at the same time I practiced my vocabulary and listening skill” (WP-014, sic). P-016 makes a similar remark, but this time about pronunciation: "I learned about ways of pronunciation I didn't have idea of, just like foreign or other vs. otter" (SD-016, sic); this also has to do with self-awareness, as we showed in the preceding lines. Similarly, participants were able to integrate vocabulary and specific sub-areas of pronunciation, such as mastering the symbols of the International Phonetic Alphabet. In P-004's words: "I would say that I liked the project, it helped me learn a lot of vocabulary that I didn't know and it also helped me recognized the symbols used in transcription" (WP-004, sic). In the final portfolio, this same student makes a similar remark, but includes a more detailed description of how she managed to integrate the pronunciation sub-skills:

I also decided after the first week that I needed to add something more to the plans so that is why I started to do the transcription for each word, that was challenging because I was unfamiliar with the 
symbols and I was not sure of what they meant, but as time went by I would listen to the pronunciation while looking for the transcription and I could read most of the symbols, specially the vowels." (FPP004, sic)

An important fact from this quotation is that skills integration was meaningfully aligned with the contents from other courses the students were taking. Participant 4's transcriptions were based on vowels because while this project was being run, she was also taking a pronunciation course (LLI-200 Vowels).

So far, results show generally positive outcomes in terms of time management, self-awareness and goal-setting, sense of achievement, and skills integration, whereas the following section analyzes a small portion of the data which displayed evidence of academic frustration.

\section{Academic Frustration}

Data for this category was not abundant, but we find it reasonable to include a few comments that suggest some degree of frustration. To clarify the construct under analysis, we will operationalize frustration as "a kind of negative emotion stimulated upon encountering a barrier to satisfying one's wants, goals, or expectations, which disrupts the ongoing action," as proposed by Gulzar, Yahya, Nauman, Mir, and Mujahid in a study about frustration in university students in Pakistan. ${ }^{54}$

Evidence shows three instances where academic frustration was present. In the final portfolio, P-007 describes a situation where what he planned to do on the following week did not adjust to the contents studied in class: "The most difficult part was to put what I will do next week. In some cases I wrote 'I will listen to a song,' but I could not find a song that adjusted to the topic studied in class. Because of this I felt really stressed for not being able to do what I said" (FP-007, sic). Furthermore, P-009 remarks his feelings of confusion when attempting

54 Shazia Gulzar, Farzan Yahya, Muhammad Nauman, Zarak Mir and Syed Hassaan, "Frustration among University Students in Pakistan," International Research Journal of Social Sciences 1, 14: (2012): 7-15 (8). 
to pronounce some sounds in English: "I learned a lot, but with some words the sound is very similar and I get confused" (WP, P009, sic). Lastly, P-003 highlights issues understanding spoken input from a video she watched: "I tried to watch a video, but it is very difficult because the person speaks very fast and I do not understand some words the person said" (WP-P003, sic).

Isolated as they may appear, these comments provide evidence that students did struggle to complete the project. They also suggest that participants felt free to be honest in their assessments, a feature which adds up to content validity.

\section{Discussion of Findings}

As already stated, this study set out to assess the influence of self-evaluation on fostering learner autonomy (LA) in EFL. To articulate a theoretical discussion of the findings, the lines below recur to empowerment pedagogy (EP) and complexity theory (CT) as theoretical underpinnings to make sense of the results. We begin with a summary of main findings; then we turn to analyzing such findings in the light of EP and CT; and then we assess how results from previous studies on LA should be taken with caution. Broadly, the findings suggest a connection between self-evaluation and the promotion of LA in areas such as time management, self-awareness and goal setting, sense of achievement, and skills integration; however, they also indicate instances of academic frustration at different points during the time frame studied.

From the theoretical lens of EP, much of the positive outcome might be explained by the fact that students were given the opportunity to identify their own learning needs and to set goals to meet them. In agreement with Torres' understanding of EP, the students in this project were placed at the center of instruction, given a chance to choose their own learning strategies, and offered a space to become 
agents of change. ${ }^{55}$ These results also correlated with opportunities for individual and collective decision making, and with giving every participant a voice. ${ }^{56}$ However, as anyone who examines the issue in detail can presume, power relations will not cease to exist simply because students are given a chance to take central stage in the learning process. The cases of academic frustration are but one example that power was also present in the POI project itself since it accounted for a total of $20 \%$ of the course's final mark. In other words, while empowerment can make learning a democratic process, it does not necessarily make it a liberating one. ${ }^{57}$

From the perspective of $\mathrm{CT}$, findings should be taken with a good dose of caution. An uncritical mind may assume a cause-effect relation between the students' reported positive results and the actual development of LA, but CT stays away from these hasty generalizations. Because the classroom is a scenario of utmost complexity, it would be rather impulsive to propose that the findings derive exclusively from the POI project, an idea that has been tackled by Reinders when explaining the elusive nature of researching LA:

Another, perhaps more important, problem is related to the question of whether the characteristics of good language learners cause success in language learning, or whether these characteristics are simply correlated with better learning outcomes. It may be possible to be a successful language learner, even without being proactive, for example. It just may happen to be that more successful learners are also, generally speaking, more proactive. In other words, research on the good language learner may not have a great deal of explanatory power. ${ }^{58}$

55 Torres, 92.

56 Loizou and Charalambous, 441.

57 Ellsworth (1989), qtd. in Johnston, 558.

58 Reinders, 41. 
Instead, CT warns us against proposing premature solutions to educational needs, and celebrates the chaos that surrounds every teaching and research event. The implication of this premise is that, in addition to questioning the positive results of the current study, we should also question the solutions suggested (in varying degrees) in previous studies conducted in Costa Rica and elsewhere (e.g., Barrantes and Olivares; Chaves and Zamora; López; Gamboa and Sevilla (2017), mentioned above; and many others).

\section{Concluding Remarks}

Thus far, despite the blunt warnings of complexity theory, our study makes several noteworthy contributions:(1)For theory, it expands the bulk of literature on self-evaluation and LA; (2) for classroom practice, the project's methodology could be reconstructed in other EFL programs; and (3) for curricular authorities, the study yields raw material for teacher training, materials selection, assessment, and professional development. In terms of technical limitations, we can speak chiefly about two: (i) the use of a limited sample, which makes findings non-transferrable to larger populations, and (ii) threats to internal validity such as the Hawthorne effect, where participants may modify their behaviors as a result of being immersed in research. Those limitations can be overcome in further research by enlarging sample sizes and varying the sampling strategies, by not revealing the research intentions and goals until the end of the process, and by conducting action research in contexts outside the higher education sphere.

In Costa Rica and elsewhere, education has historically operated as a subsystem of politics, which sets the rules of the game by deciding upon budget allocation for schools, universities, and study centers. But the multiple rationalities that come into play in the political scenario ${ }^{59}$ are often so detached from the classroom realities that institutional authorities end up abiding by the rules of these somewhat distant

59 On "rationalities," see Tudor, 118-119. 
authorities. To make matters worse, the latter are in turn influenced by external agents such as finance institutions, larger state organs, and a host of international organizations which sooner or later impose their own educational agendas on local curricula. This reduces teaching to meeting international standards that rarely match the students' needs and often fail to respond to the demands of the labor market, let alone the fact that learning ceases to be an edifying experience.

While we are aware that these dynamics are too powerful to confront, we also believe that at least classroom researchers should be bold enough to report on the positive and the negative results of their projects. They should also be optimistic enough to propose seemingly unthinkable initiatives such as investing more on learner-centered instruction, fostering critical thinking skills, harmonizing the cognitive and the emotional dimensions of education, ${ }^{60}$ and promoting shifts in paradigms to meet the current needs of our evolving humanity. Will this ever happen? Will authorities listen to the evidence discussed herein and elsewhere? Only time will tell, certainly, but we are at least starting to gather evidence on the positive, the negative, and the "impossible" changes needed to make education a more democratic, more empowering, and more liberating enterprise for all.

60 See Gamboa and Sevilla (2017) 237. 


\section{Appendix 1: Autonomy Assessment Instrument}

Objective: to collect qualitative and quantitative data about students' educational needs in terms of autonomy development for EFL learning

PART A: Rate your level of agreement with the following statements - regarding how much they reflect how you think or feel personally. Your honesty will contribute to the validity of the results.

$1=\mathrm{I}$ totally disagree; 2 =I generally disagree; $3=\mathrm{I}$ have reservations; $4=\mathrm{I}$ agree to a certain extent; $5=\mathrm{I}$ generally agree; $6=\mathrm{I}$ totally agree

\begin{tabular}{|c|c|}
\hline In my English learning experience so far, I... & \\
\hline 1. am able to organize my time effectively. & $1 \square 2 \square 3 \square 4 \square 5 \square 6 \square$ \\
\hline 2. am able to set clear learning goals. & $1 \square 2 \square 3 \square 4 \square 5 \square 6 \square$ \\
\hline $\begin{array}{l}\text { 3. devote a consistent number of weekly hours to } \\
\text { reinforce my learning. }\end{array}$ & $1 \square 2 \square 3 \square 4 \square 5 \square 6 \square$ \\
\hline 4. take charge of my own responsibilities. & $1 \square 2 \square 3 \square 4 \square 5 \square 6 \square$ \\
\hline 5. think over my learning actions of the week. & $1 \square 2 \square 3 \square 4 \square 5 \square 6 \square$ \\
\hline 6. become aware of my role as a learner in class. & $1 \square 2 \square 3 \square 4 \square 5 \square 6 \square$ \\
\hline $\begin{array}{l}\text { 7. clearly see how classes contribute to my } \\
\text { learning. }\end{array}$ & $1 \square 2 \square 3 \square 4 \square 5 \square 6 \square$ \\
\hline $\begin{array}{l}\text { 8. am motivated to go beyond what is required in } \\
\text { the courses. }\end{array}$ & $1 \square 2 \square 3 \square 4$ \\
\hline 9. am able to become an independent learner. & $1 \square 2 \square 3 \square 4 \square 5 \square 6 \square$ \\
\hline $\begin{array}{l}\text { 10. am able to identify my weaknesses and create } \\
\text { action plans to work on them }\end{array}$ & $1 \square 2 \square 3 \square 4 \square$ \\
\hline
\end{tabular}

PART B: Answer the following questions according to your own experience.

1. Do you consider yourself an autonomous English language learner? If so, give a few examples of how you are an autonomous English language learner. If not, briefly explain why. 
2. What have been some of your main challenges in learning English?

3. What can you do to overcome those challenges?

\section{Appendix 2: Plan for Improvement Sheet}

Week no. Sub-skill/Topic to Work on:

Date: Student's Name:

Objective: to give the students a chance to plan, implement, and assess weekly activities to improve their speaking and listening skills.

Instructions:

1. Write the correct information under each category presented. The information you write must refer to the present week.

\begin{tabular}{|c|c|c|c|c|}
\hline $\begin{array}{c}\text { Content to } \\
\text { reinforce } \\
\text { this week }\end{array}$ & $\begin{array}{c}\text { Activity } \\
\text { assigned for } \\
\text { this week }\end{array}$ & $\begin{array}{c}\text { Schedule for } \\
\text { the activity } \\
\text { assigned }\end{array}$ & $\begin{array}{c}\text { Evaluation of } \\
\text { the activity's } \\
\text { effectiveness }\end{array}$ & $\begin{array}{c}\text { Annotations } \\
\text { for next week }\end{array}$ \\
\hline & & & & \\
& & & & \\
\hline
\end{tabular}

2. Write a short reflection assessing your plan for this week. You may use the following questions as a guide.

- How did the different activities help you learn the contents for this week?

- What part of the content, if any, were you unable learn?

- How difficult (or easy) was it for you to meet the schedule you set to accomplish the activities? 


\section{Appendix 3: Student Diary}

Week $\mathrm{N}^{\circ}$

Date:

Student's Name:

Objective: to reflect on one's challenges and accomplishments in listening and speaking skills development

Instructions: Reflect upon your progress this week by using the prompts
provided. Hand in your diary entries to the professor for feedback and
recommendations for further improvement.
1. In general, how did you feel about this week's lessons? Why did you feel
that way?
2. How would you assess your participation in this week's lessons?
3. In what two ways have this week's lessons contributed to the improvement
of your speaking and listening skills?
Instructor's Comments:

